\title{
The Use of YouTube Social Media to Educate Society through Virtual Literacy during COVID-19 Pandemic
}

\author{
D Melisa ${ }^{1}$, P Pawito $^{2}$, Y Slamet ${ }^{3}$ \\ ${ }^{1}$ Master of Communication Study Program of Faculty of Social and Political Sciences, \\ Sebelas Maret University, Surakarta, Indonesia, ${ }^{2}$ Departement of Communication Science of Faculty of \\ Social and Political Sciences, Sebelas Maret University, Surakarta, Indonesia \\ ${ }^{3}$ Departement of Sociology Science of Faculty of Social and Political Sciences, Sebelas Maret \\ University, Surakarta, Indonesia \\ 1'melisadora@student.uns.ac.id, 22pawito_palimin@staff.uns.ac.id, 33yuliusslamet48@gmail.com
}

\begin{abstract}
The existence of new media with the rapid development of information and communication technology makes a massive change in various aspects of life. Information and communication technology makes the world borderless so that education and literation toward society possible to do anytime and anywhere. Virtual literacy by using social media Youtube is a solution during the COVID-19 pandemic. The concept of virtual literacy is used by the Ministry of Agriculture's Library in educating society, especially farmers. A qualitative descriptive approach is employed in this study especially observation. This study used media theory to observe the use of YouTube social media as a communication medium in conducting virtual literacy in society. The results showed that virtual literacy conducted by the Ministry of Agriculture's Library was not optimal yet, because there are still many internet users not accessing the YouTube channels, seen from the lack number of subscribers. Internet networks that are not spread evenly in Indonesia become one of the factors the low access of the public to the Youtube channel of the Ministry of Agriculture's Library.
\end{abstract}

Keywords: New Media, YouTube, Education, Virtual Literacy, COVID-19, Ministry of Agriculture's Library.

\section{Introduction}

Education is important thing as it seems that almost all countries in the world make it as a priority. In Indonesia, education is regulated in the 1945 Constitution Article 31 paragraph 1 mandates that: Every citizen has the right to education. Education is not only the responsibility of the Ministry of Education and Culture but also other departments [1]. Libraries also take a role in providing education to the society. In-Law Number 43 the Year 2007 concerning Library chapter 1 article 1 it is mentioned; The library is an institution that manages the collection of written works, printed works, and/or recorded works professionally with a standardized system to fulfill the educational, research, preservation, information and recreation needs of the users. In fulfilling educational needs, libraries are required to provide collections according to the needs of the users. In article 5 of Law 43/2007 concerning Libraries regulates rights, obligations towards libraries, that; (1) the society has the same right to obtain services and to use and utilize library facilities; (2) society at remote, isolated or backward areas as a result of geographical factors have the right to obtain library services specifically; (3) people who have physical, emotional, mental, intellectual and/or social 
disabilities, and/or disabilities have the right to obtain library services that are adjustable to their abilities and limitations [2].

Refers to the Presidential Regulation of the Republic of Indonesia Number 72 of 2018 concerning the 2019 government work plan, equitable development for quality growth, has a role in improving the quality of human resources and improving the welfare of the society. The library as a center of information literacy and a center of activity can be a space for longlife learning to develop the potential and empowerment of the society [3]. There are two targets/indicators to be achieved, namely improving the quality of services based on social inclusion for welfare and the realization of the library as a preserver of the national cultural treasures, as shown in the table below:

Table 1.Objectives and Indicators of Library Development

\begin{tabular}{|c|c|c|c|c|c|}
\hline Number & Objectives/Indicators & 2016*) & 2017*) & $2018 * *)$ & $2019 * *)$ \\
\hline 1. & \multicolumn{5}{|c|}{ Increasing the quality of library services based on social inclusion for welfare } \\
\hline & $\begin{array}{l}\text { a. The value of people's reading } \\
\text { fondness }\end{array}$ & $26,1^{a)}$ & $36,5^{a)}$ & 43,0 & 50,0 \\
\hline \multirow[t]{2}{*}{2.} & \multicolumn{5}{|c|}{ The realization of the Library as a Preserver of the National Culture Treasure } \\
\hline & $\begin{array}{l}\text { a. Percentage increase in the } \\
\text { preservation of library materials } \\
\text { and ancient manuscripts }(\%)\end{array}$ & $15,31^{a)}$ & $15,44^{a)}$ & 15,63 & 16,48 \\
\hline
\end{tabular}

Source: ${ }^{\text {a) }}$ National Library of Indonesia (processed), 2018.

Note: *) Temporary Data; ${ }^{* *}$ ) Target.

Source: Perpres No. 72 of 2018 concerning 2019 Government Work Plan

The COVID-19 pandemic impacts all aspects of life including library services. During the COVID-19 pandemic and the New Normal era, there was a change in library services. For direct library service (on-site service) amount of visitors or users is limited due to the health protocol, but this does not inhibit the dissemination of information and literacy to the society. People who cannot come to the library still get online service. An online service is a way to provide education to the community to be able to use information technology products. In the 4.0 revolution era, people are required to have the ability to master information technology.

In communication science theory, information technology is part of new media. Mark Poster in his book 'The Second Media Age' writes that a new era with technology and interactive communication networks that is the internet will bring changes to society. The new era created three important changes in media theory; 1) The concept of media from mass communication changed from a broader scope into personal that signed by the presence of personal computers, tablets, and smartphones. 2) New forms of media use, from personal information to the interaction of knowledge known as the concept of the network society. 3) The change in media theory from relative obscurity to new popularity that continues today[4].

Although access to the internet is very massive in many countries in the world, in Indonesia the population accessing the internet is still $39.90 \%$ in 2018 based on data from the Central Statistics Agency [5]. Meanwhile, the data released by the Indonesian Internet Service Providers Association (APJII) states that in 2018 as many as 171.17 million people of Indonesia out of 264.16 million people are internet users. The total internet users are $64.8 \%$ with the contribution of users in the domination of the island of Java $55.7 \%$, Sumatra $21.6 \%$, Papua 10.9\%, Kalimantan 6.6\%, Sulawesi and Maluku 5.2\%. The unequal use of internet networks in Indonesia is influenced by some factors, one of which is geographical conditions [6]. 
By using information and communication technology, libraries should no longer have obstacles in providing education to the society during the COVID-19 pandemic. Libraries, in this case, can take a role to increase the utilization of information and communication technology by the direction of government policy. Some of the efforts that have been made are making information technology-based service products such as virtual literacy services, procurement of collections that can be accessed through applications, and providing reading material in the form of books and national and international journals.

One of the library service strategies undertaken in educating the public by utilizing communication technology, especially social media, is carried out by the Ministry of Agriculture Library through the YouTube channel. Education to the community, especially farmers, continues to run even without face to face. Changes in library services from previously direct or face-to-face to be virtual certainly affect the social aspects of society. For changes to be accepted, the delivery of messages must be working. Communication is about maintaining changes. [7] For social changes that are expected to go according to plans and expectations, there must be an appropriate strategy in the communication message to the communicant. According to Everett Rogers, communication strategies are designs designed to change human behavior on a larger scale through the transfer of new ideas [8].

This study attends to examine based the above mention that is to explain how the Ministry of Agriculture's library educates the public during the pandemic COVID-19, through virtual literacy by using social media YouTube.

\section{Method}

A qualitative descriptive approach is employed in this study, especially observation on the content of Youtube publish by the Ministry of Agriculture's Library. The categorization of analysis is to find out how the library educates society through virtual literacy by using social media Youtube. Descriptive research merely describes the situation or research event, does not test hypotheses or make predictions. Besides, this method focuses on observation and scientific atmosphere. Researchers only act as observers, only make a category of behavior, observe symptoms, and record them in his observation book [9].

This study used media theory to observe the use of YouTube social media as a communication media in conducting virtual literacy to the public, especially during the pandemic COVID-19.

Previous studies related to the use of social media are; 1) How social media alcohol marketing is utilized for alcohol promotion in different national contexts (India and Australia) [10]. 2) Undergraduate music education students created music videos during an informal music learning project in an introduction to music education and technology courses at a large, Midwestern, public university[11]. 3) Specific patterns of facial expressions predict the popularity of YouTube videos among users of social media [12]. Previous studies that used qualitative descriptive methods are; about how to use social media with a good plan [9], and the second one is about Youtube as one of the media is used by people in communicating ideas through creativity [13]. 


\section{Result And Discussion}

The world is currently in the third phase described by Alvin Toffler[14] in his book entitled "Future Shock" is the phase in which the world is in support of advances in information and communication technology, data processing, applications of world and aerospace flights, alternative energy, biotechnology, ceramic engineering, microelectronics. Naisbitt [14] also stated that the world has now entered a new era where it is marked by an information explosion accompanied by another main tendency that increasingly illustrates that there is a transition from the industrial society to the information society. The current economic system depends on the production, management, and utilization of information.

YouTube social media as a new form of media is currently popular among the people to convey information or just express themselves to get responses or attention from the public. Youtube is becoming a phenomenon and influential all over the world which only has internet access [13]. Utilization of information through social media youtube has also become a trend for government agencies to run and socialize programs of institutions. Ministry of Agriculture Library through its YouTube channel several times doing virtual literacy to the audience. The audience is not only the staff department or agency under the guidance of the Ministry of Agriculture, farmers, observers of agriculture but also public in general.

After observing the Ministry of Agriculture's Library YouTube channel, virtual literacy started in March 2020 along with the outbreak of the COVID-19 in Indonesia. The virtual literacy program, first aired on the Ministry of Agriculture's Library YouTube channel titled Joint Synergy to Face COVID-19 in which the purpose is to build employee's awareness about the COVID-19 outbreak [15]. The activities carried out through the zoom meeting and live streaming on YouTube with the speaker from the Bogor Health Office. Virtual literacy through zoom meetings and YouTube live streaming is not only enjoyed by meeting participants but also the public in general.

Before the existence of the virtual literacy program, the Ministry of Agriculture's Library since seven years ago on September 14, 2012, had started uploading videos about the Ministry of Agriculture's activities and videos related to agriculture such as technology and agricultural cultivation. Until now, the Ministry of Agriculture's Library YouTube channel has 170 video content about virtual literacy, webinars, and agricultural technology and cultivation videos. For video content in the form of virtual literacy and webinars, the duration ranges from 2 to 3 hours, while videos about technology and agricultural cultivation generally take about 10 to 20 minutes. Viewed from the audience, the graph fluctuates with the highest view of 518,411 views on content titled Fattening Cows with Cheap Feed uploaded in 2014, which lasts 16 minutes 48 seconds. The video is about the visitation of the Agency Secretary to the Library Visit Day booth got the lowest view of 17 with a video duration of 30 seconds. Until now, the subscribers of the Ministry of Agriculture's YouTube channel are 21 thousand 900. This number is still low if compared to 171.17 million internet users in Indonesia.

The information conveyed by the speakers on virtual literacy and webinars gets positive responses from participants or viewers by asking some questions. This indicates that the message delivered by the communicator was received by the communicant. The amount of webinar participants through the zoom meeting and the audience on the YouTube live streaming channel also indicates that societies are getting familiar with the progress of information and communication technology.

The virtual literacy strategy did by the Ministry of Agriculture Library is an attempt to overcome the impact of disruption of the industrial revolution 4.0 in which the use of automatic machines is integrated with the internet network. Farmers must be able to adapt to 
the development of communication and information technology by mastering the use of the internet. BPS data for 2018 states that the potential of the internet at the farmer and rural level is $93.9 \%$. Most internet users access the internet through smartphones/cellphones (96.6\%). Based on Village Potential data (Podes) in 2018, there were 77,172 (91.95\%) villages that had been able to receive cellular telephone signals. This number increased compared to 2011 and 2014 , where only $70,610(89.82 \%)$ villages were able to receive cellular telephone signals in 2011 and $74,473(90.61 \%)$ villages in the year 2014. Of the total Indonesian farmers $(33.4$ million farmers), 4.5 million farmers were using the internet (13\%). In general, internet signals have been distributed evenly in most villages and have been reached by $2 \mathrm{G}, 3 \mathrm{G}$, and $4 \mathrm{G}$ signals. Based on these data, the industrial era 4.0, one of which uses the connection of all devices to the internet can be used as initial capital for digital transformation in agriculture [16]. This is stated in the strategic plan of the Ministry of Agriculture 2020-2024.

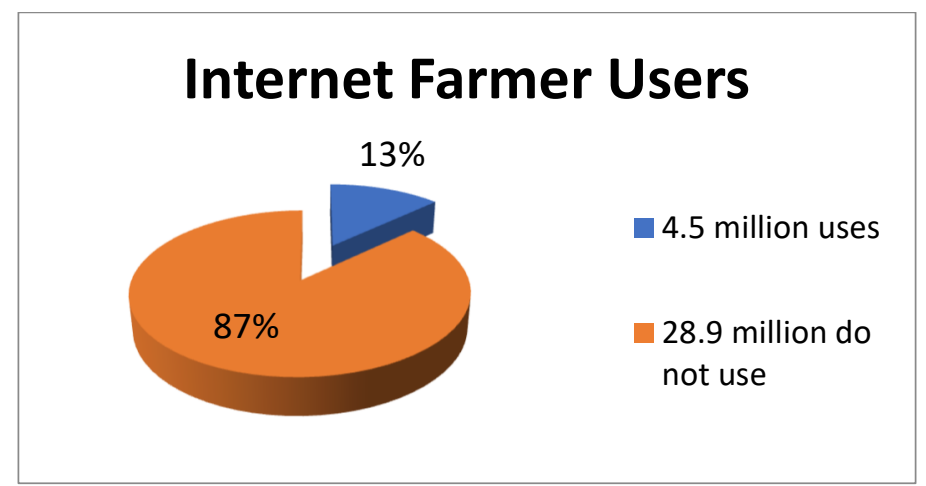

Fig.1. Farmers Using the Internet in 2018 (Source: BPS, 2018) Source : Ministry of Agriculture Strategic Plan 2020-2024

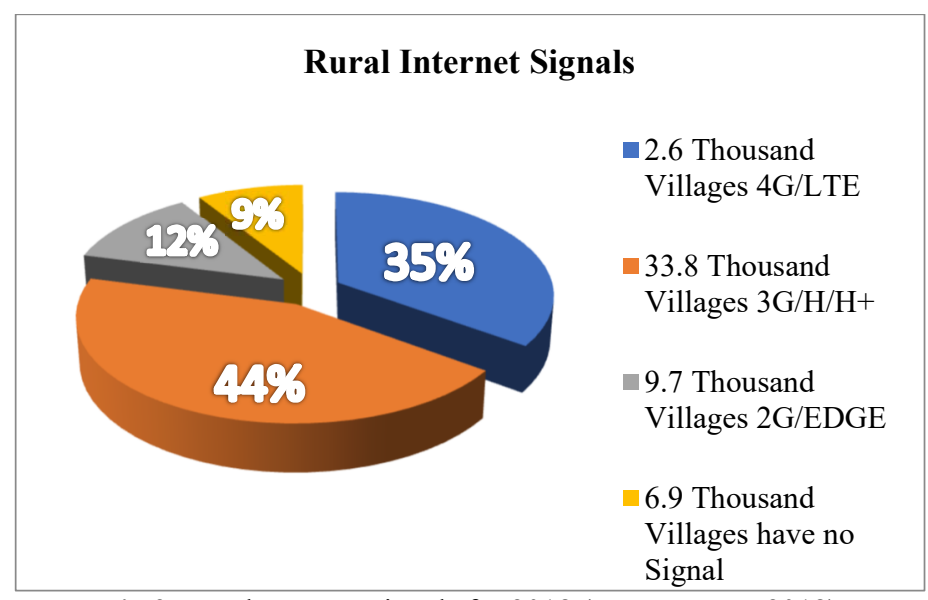

Fig.2. Rural Internet Signals for 2018 (Source: BPS, 2018)

Source : Ministry of Agriculture Strategic Plan 2020-2024

The communication strategy did by the Ministry of Agriculture's Library should be followed by other libraries in Indonesia. This effort seems difficult because the distribution of information technology networks in Indonesia is still uneven yet. Some problems or obstacles 
might found in managing the information technology-based libraries [17]: a). Inadequate infrastructure such as telecommunications, the internet, and computers. Teledensity conditions in Indonesia in 2018 amount to 119,339. This number is lower than Thailand's 180,183, Singapore 148,822, and Malaysia 134,526 [18]. b). Lack of coordination in the construction of ICT (Information and Communication Technology) facilities which cause overlapping in the provision of facilities and infrastructure. c). Human resources who master ICT are still very limited. d). The low awareness of library managers of the benefits that can be obtained from the application of ICT.

\section{Conclusions}

Social media as part of the new media become a necessity for the industrial revolution 4.0 era. Not only individuals but the also government organization started to use social media in conducting programs such as socialization and literation. Social media also used by the Ministry of Agriculture's Library to educate society through virtual literacy by using YouTube channels. There is 170 video content on the Youtube of the Ministry of Agriculture's Library contains virtual literacy, webinars, technology videos, agricultural cultivation, and also information about activities in the Ministry of Agriculture. The subscriber of the Ministry of Agriculture's Library Youtube channel is 21 thousand 900. This number still low compared to 171.17 million internet users in Indonesia. It means only a few people, especially farmers who been educated through virtual literacy.

\section{References}

[1] Http://www.dpr.go.id/jdih/uu1945, Undang-Undang Dasar Negara Republik Indonesia Tahun 1945. 1945.

[2] P. N. R. Indonesia, Undang-Undang Nomor 43 Tahun 2007 Tentang Perpustakaan. 2007.

[3] S. K. R. Indonesia, Peraturan Presiden Republik Indonesia Nomor 72 Tahun 2018 Tentang Rencana Kerja Pemerintah Tahun 2019. 2018

[4] J. G. O. Stephen W. Littlejohn, Karen A. Foss, Theories Of Human Communication Eleventh Edition. 2017.

[5] Badan Pusat Statistik, Stastistik Telekomunikasi Indonesia 2018. 2018.

[6] Asosiasi Penyelenggara Jasa Internet Indonesia, "Hasil Survei Penetrasi \& Profil Perilaku Pengguna Internet Indonesia 2018," 2019. [Online]. Available: www.apjii.or.id.

[7] S. J. Patterson and J. M. Radtke, Strategic Communication for Nonprofit Organizations. 2009.

[8] J. A. Aryawan, "Strategi Komunikasi untuk Pengembangan Kawasan Desa Wisata (Studi Kasus Implementasi Strategi Komunikasi Pemerintah Kabupaten Sragen Untuk Membangun Partisipasi Masyarakat Dalam Program Pengembangan Kawasan Desa Wisata Pertanian Organik Betisrejo Sragen,” 2013.

[9] P. Wydaswari, S. Dida, and F. A. A. Prastowo, "Strategi Perencanaan Humas Media Sosial Radio OZ sebagai Upaya Transformasi Pendengar," PRofesi Humas Jurnal Ilmiah Ilmu Hubungan Masyarakat, vol. 3, no. 2, pp. 159-176, 2019, doi: 10.24198/prh.v3i2.15711.

[10] H. Gupta, T. Lam, S. Pettigrew, and R. J. Tait, "Alcohol marketing on YouTube: Exploratory analysis of content adaptation to enhance user engagement in different national contexts," $B M C$ Public Health, vol. 18, no. 141, pp. 1-10, 2018, doi: 10.1186/s12889-018-5035-3.

[11] C. Cayari, "Participatory culture and informal music learning through video creation in the curriculum," International Journal of Community Music, vol. 8, no. 1, pp. 41-57, 2015, doi: 
10.1386/ijcm.8.1.41 1.

[12] P. Lewinski, “Don't Look Blank, Happy, or Sad: Patterns of Facial Expressions of Speakers in Banks' YouTube Videos Predict Video's Popularity Over Time," Journal of Neuroscience, Psychology, and Economics, vol. 8, no. 4, pp. 241-249, 2015, doi: 10.1037/npe0000046.

[13] A. R. Sulaeman, A. Fazri, and F. Fairus, "Strategi Pemanfaatan Youtube Dalam Bidang Dakwah Oleh Ulama Aceh," Communicatio, vol. 11, no. 1, pp. 81-93, 2020, [Online]. Available:

https://journal.budiluhur.ac.id/index.php/comm/article/view/1009/777\%0Ahttps://lens.org/072977-525-779-442.

[14] Kristina K, "Transformasi Perpustakaan Bagi Generasi Z. PROSIDING Disruptive Technology: Opportunities and Challenges for Libraries and Librarians Trawas-Mojokerto," in Seminar dan Call for Papers Dalam Rangka Dies Natalis Universitas Surabaya ke-50 Tahun 2018, 2018, pp. 394-395, [Online].

Available: https://www.researchgate.net/publication/331371645_Transformasi_Perpustakaan_Bagi_Gener asi_Z.

[15] Pustaka Kementerian Pertanian. .

[16] Kementerian Pertanian Republik Indonesia, Rencana Strategis Kementerian Pertanian 20202024. 2020 .

[17] Gardjito, "Kebijakan Pengelolaan Perpustakaan Berbasis Teknologi Informasi (TI)," Visi Pustaka, 2005.

[18] CEIC data, "Indonesia Teledensitas: Seluler,” 2019. 